\title{
Japan's scientific whaling not a commercial operation
}

Tokyo

JAPAN has been severely criticized for its plans to carry out 'scientific whaling' in the Antarctic during the coming austral summer. And, under threat of retaliation by the United States, the Fisheries Agency has drastically cut Japan's proposed whale catch for the next season. But what are Japan's plans for research, what effects is it likely to have on whale stocks and is it really a commercial operation in disguise?

Earlier this year, Japan proposed catching 825 minke wales and 50 sperm whales for 'research purposes'. But the proposal was immediately condemned by environmentalist groups as a device intended to skirt the International Whaling Commission's (IWC) moratorium on commercial whaling (see Nature 326, 732; 1987). And at the IWC annual conference in Bournemouth (UK) in June, a US resolution was adopted calling for a scientific committee to review proposed research programmes.

Despite the IWC resolution, Japan pressed ahead with its plans, and in July the Agriculture, Forestry and Fisheries Committee of the lower house of the Diet unanimously decided to go ahead with the research. But the United States threatened to halve Japan's quota in the US 200-mile economic zone by invoking the MagnusonPackwood Act, a domestic law designed to curtail the fishery catch of nations that ignore IWC recommendations; the US ambassador to Japan, Mike Mansfield, even suggested that Japan's proposal for scientific whaling would adversely affect deliberations on the omnibus trade bill now before Congress.

In the wake of the Toshiba affair, Japan had little choice but to retreat, and the Fisheries Agency has cut the proposed minke whale catch to 300 (no sperm whales are to be taken). This is a far cry from the 1960s, when Japan used to catch over 20,000 whales a year, valued at around $¥ 30,000$ million ( $\$ 200$ million). But the irony is that Japan is not the country responsible for bringing some species of whale to the brink of extinction.

It was US and European whaling fleets in the $1930 \mathrm{~s}$ that used to catch tens of thousands of blue whales in the Antarctic, severely depleting stocks. And it was US whalers at the turn of the century that brought the bowhead whale in the Bering Sea and Arctic to the brink of extinction. Current US estimates place the population of bowheads at only about 2,000. Nevertheless, the United States, through IWC actions, continues to support aboriginal subsistence whaling of 20-30 bowheads per year to try and preserve Eskimo culture.

In contrast, the IWC estimate the popu- lation of large adult minke whales in the Antarctic at $280,000(430,000$ if all sizes are included), while that of sperm whales was placed at 367,000 in 1979. And IWC estimates of the net annual addition of sperm whales $(2,600$ per year $)$ far exceeds Japan's proposed take of 50 sperm whales. But the proposal has now been dropped in the face of US opposition.

The annual net addition of minke whales to the Antarctic population is uncertain. And, according to Kunio Arai, head of the Japan Whaling Association, one of the main puposes of Japan's research would be to determine natural mortality and pregnancy rates in the minke whale. Arai says that, under Japan's proposal, a new whale research institute will be established in the next few months with five scientists on the staff. Another 15-20 researchers from universities and research institutes throughout Japan will participate in the proposed programme for next season.

In 1947 a whale research institute was established in Tokyo with funds from the whaling industry, and the institute published around 400 reports on the biology and ecology of whales, many of them by leading cetologists, such as Masaharu Nishiwaki and Hideo Omura. But with the decline of commercial whaling the institute has been struggling to survive.

While it is debatable whether $20-25$ researchers could handle 300 minke whales a year, it is absurd for the Western press and environmentalists to suggest that the Japanese proposal is a commercial operation in disguise. The costs of sending the 23,000-ton mother ship, the Dai San Nisshin Maru, with two catcher boats to the Antarctic for several months are enormous, and Arai says that with a catch of only 300 minke whales the operation will be well into the red; the balance will be covered by the Ministry of Agriculture, Forestry and Fisheries which has allocated $¥ 350$ million ( $\$ 2.4$ million) for whale research in this fiscal year.

The US has expressed "appreciation" for Japan's revised plans in talks with Goroku Satake, director-general of the Fisheries Agency. But the decision will be left to the scientific committee of the IWC.

David Swinbanks

\section{Munich}

WEST German doubts about the proposed European space shuttle Hermes and the space station Columbus leave the threelegged European Space Agency (ESA) programme with just a single leg to stand on.

The West Germans, who are supposed to contribute 30 per cent to the costs for the Hermes shuttle and 38 per cent to the costs for Columbus, have made their reservations known privately in advance of the 9-10 November ESA ministerial meeting at the Hague. Total costs for the three projects - Hermes, Columbus and the booster rocket Ariane - are now estimated to surpass DM 30,000 million over the next ten years. The West German share will be more than 25 per cent.

Despite official protestations to the contrary, Ariane 5 is the only one of the three new ESA projects that the West Germans seem likely to support. The official government line still supports manned space exploration, despite what the Research Ministry calls "occasional criticism". Jürgen Rüttgers, a Christian Democratic member of the Bundestag Research and Technology Committee, said that Europeans will be shut out of space if they simply wait for US advances in rocket and shuttle technology.

But West Germany has serious reservations about both Columbus and Hermes. Columbus, though technically agreeable to West Germany, is hamstrung by doubts about its potential use by the US military. This is less of a problem for West
Germany than for non-NATO members of ESA such as Switzerland, but West Germany is also put off by a perceived US wish to monopolize research results obtained on Columbus, even if the discoveries are made in a non-US laboratory within the space station.

The doubts about Hermes are even more serious, echoing the rumblings coming out of Great Britain (see Nature 329, 660; 1987). Even Rüttgers said that the West Germans will reserve judgement on Hermes until all of the technical problems have been settled. These problems are said to be quite serious.

In a forceful speech at the West German Aerospace Research Establishment in Cologne on 21 October, French President Francois Mitterrand called upon West Germany for its unconditional support for Hermes. The speech illustrates the political dimensions of the struggle within ESA, and some West German officials see it as a potential blunder by Mitterrand.

The entire debate over doubling the costs of the three ESA programmes could hardly have come at a worse time for West German politicians, who are involved in an internal conflict over tax reform.

The three parties in the ruling coalition are due to meet on 3 November to discuss guidelines for the newly created West German space agency (see Nature 328, 6; 1987). Then the full cabinet will sit on 4 November to determine the West German position for the ESA meeting the following week. 